\title{
HUBUNGAN PENGGUNAAN GADGET DENGAN PERKEMBANGAN SOSIAL DAN EMOSIONAL ANAK PRASEKOLAH DI KABUPATEN LAMPUNG SELATAN
}

\author{
Riyanti Imron* \\ Dosen Jurusan Kebidanan Poltekkes Tanjungkarang
}

\begin{abstract}
Anak-anak yang menggunakan gadget jumlahnya meningkat dua kali lipat dari 38 persen menjadi $72 \%$ antara 2011 dan 2013. Menurut Departemen Kesehatan RI 0,4 juta (16\%) balita Indonesia mengalami gangguan perkembangan sosial dan emosional. Dari studi pendahuluan diperoleh databahwa anak yang penggunaan gadgetnya rendah, $67 \%$ menunjukkan perkembangan sosial dan emosional yang baik. Anak yang penggunaan gadgetnya tinggi, $71 \%$ mengalami hambatan perkembangan sosial dan emosional. Penelitian ini bertujuan untuk mengetahui hubungan penggunaan gadget dengan perkembangan sosial dan emosional anak prasekolah. Penelitian ini menggunakan desain analitik cross sectional. Jumlah sampel merupakan total populasi sebanyak 96 responden. Data penelitian dikumpulkan dengan menggunakan kuisioner. Analisis data univariat menggunakan persentase dan analisis bivariat menggunakan uji chi square. Hasil analisis univariat menunjukkan penggunaan gadget rendah sebanyak $63 \%$ dan perkembangan sosial dan emosional baik sebanyak 50,6\%. Hasis analisis bivariat dengan uji chi square menunjukkan nilai $\mathrm{p}=0,001(\mathrm{p}<0,05)$, nilai ini menyatakan ada hubungan penggunaan gadget dengan perkembangan sosial dan emosional anak prasekolah. Kesimpulan dari penelitian ini adalah ada hubungan penggunaan gadget dengan perkembangan sosial dan emosional anak prasekolah. Dari penelitian ini diharapkan para pendidik dapat memberikan materi kepada orang tua saat kegiatan parenting tentang pentingnya mengontrol dan mengawasi anak-anaknya dalam penggunaan gadget menggunakan media yang menarik dan mudah dimengerti seperti leaflet, video, atau slide.
\end{abstract}

Kata Kunci: Gadget, Perkembangan Sosial dan Emosional, Anak Prasekolah

\section{LATAR BELAKANG}

Masa prasekolah merupakan periode penting dalam proses tumbuh kembang manusia. Perkembangan dan pertumbuhan di masa itu menjadi penentu keberhasilan pertumbuhan dan perkembangan anak di periode selanjutnya. Kecepatan tumbuh kembang setiap individu satu dengan individu lainnya bervariasi, tergantung faktor-faktor yang mempengaruhinya selama proses tumbuh kembang tersebut berlangsung (Supartini, 2004). Disadari atau tidak kebiasaan lingkungan dan pemberian stimulasi terhadap anak prasekolah akan membentuk perkembangan anak. Pada saat ini seiring berkembangnya teknologi, banyak sekali yang berpengaruh pada anak salah satunya adalah penggunaan gadget.

Dewasa ini, gadget tidak hanya beredar di kalangan remaja (usia 12-21 tahun) dan dewasa atau lanjut usia (usia 22-ke atas), tetapi juga beredar di kalangan usia anak-anak (usia 7-11 tahun) bahkan ironisnya lagi gadget bukan barang asing untuk anak usia prasekolah (usia 3-6 tahun) yang belum layak menggunakan gadget (Widiawati, 2014).

Sebuah penelitian dikeluarkan oleh American Association of Pediatrics (AAP) dengan tajuk "penggunaan media menjadi dominan dalam kehidupan anak-anak zaman sekarang". Media yang paling umum digunakan anak adalah gadget, jumlah anak-anak yang menggunakan gadget meningkat dua kali lipat (dari $38 \%$ menjadi $72 \%$ ) hanya dalam kurun waktu dua tahun, antara 2011 dan 2013 (Uhls, 2016). Berdasarkan survei yang dilakukan oleh The Asian Parent Insight bersama Samsung Kidstime melalui Mobile Device Usage Among Young Kids pada awal tahun 2014 didapatkan hasil yang mengejutkan yaitu sebanyak $98 \%$ responden memperbolehkan anaknya menggunakan gadget dengan lama penggunaan lebih dari 1 jam pada setiap kali penggunaan. 
Penggunaan gadget yang berlebihan akan membawa dampak buruk bagi perkembangan sosial dan emosional anak. Dampak buruk penggunaan gadget pada anak antara lain anak menjadi pribadi tertutup, gangguan tidur, suka menyendiri, perilaku kekerasan, pudarnya kreativitas, dan ancaman cyberbullying (Iswidharmanjaya, 2014).

World health organitation (WHO) melaporkan bahwa 5-25\% anak-anak usia prasekolah menderita disfungsi otak minor, termasuk gangguan perkembangan (Widati, 2012). Departemen kesehatan RI Dalam Widati (2012), melaporkan bahwa 0,4 juta $(16 \%)$ balita Indonesia mengalami gangguan perkembangan, baik perkembangan motorik halus dan kasar, pendengaran, sosial dan emosional, dan keterlambatan bicara. Sedangkan menurut Dinas Kesehatan dalam Widati (2012), sebesar 85.779 (62,02\%) anak usia prasekolah mengalami gangguan perkembangan (Widati, 2012). Selanjutnya antara 9,5\% - 14,2\% anak - anak berusia antara nol sampai lima tahun mengalami masalah sosial emosional yang berdampak negatif terhadap fungsi perkembangan mereka dan kesiapan untuk bersekolah (Cooper;dkk, 2009).

Hasil penelitian yang dilakukan kepada beberapa keluarga di wilayah Yogyakarta pada tahun 2013, menunjukan sejak menggunakan gadget, ketika dirumah anak menjadi susah diajak berkomunikasi, tidak peduli dan kurang berespon pada saat orang tua mengajaknya berbicara (Anggrahini, 2013). Apabila hal ini berlangsung terusmenerus, dikhawatirkan akan mengganggu perkembangan sosial dan emosional pada anak prasekolah. Dimana anak-anak seharusnya dapat berinteraksi baik dengan lingkungan sekitar akan tetapi dengan adanya gadget sebuah interaksi tersebut akan mengalami sebuah gangguan.

Tidak ditemukan data mengenai penggunaan gadget dan perkembangan sosial dan emosional pada balita di Provinsi Lampung dan Kabupaten Lampung Selatan, namun berdasarkan Studi pendahuluan dilakukan peneliti di
PAUD Percontohan Tunas Ceria Tanjung Bintang pada tanggal 11 Juli 2017 terdapat 96 anak usia 3-6 tahun pada tahun ajaran 2016/2017. Peneliti mengambil sampel 10 murid. Studi pendahuluan tersebut di dapat hasil bahwa siswa yang penggunaan gadgetnya tinggi ada $30 \%$ dan yang penggunaan gadgetnya rendah ada $70 \%$. Pada anak yang penggunaan gadgetnya rendah, $67 \%$ yang menunjukkan perkembangan sosial dan emosional yang baik. Anak yang penggunaan gadgetnya tinggi, $71 \%$ mengalami hambatan perkembangan sosial dan emosional.

\section{METODE}

Penelitian ini menggunakan desain penelitian analitk Analitik dengan pendekatan Cross Sectional. Populasi dari penelitian ini adalah seluruh anak prasekolah yang diikutkan dalam program PAUD di PAUD Percontohan Tunas Ceria Tanjung Bintang Lampung Selatan tahun ajaran 2016-2017 berjumlah 96 orang dengan sampel sebesar jumlah populasi (total sampling).

Data yang dikumpulkan berupa data primer dengan teknik observasi menggunakan angket. Peneliti menyebarkan angket (kuisioner) yang berisi pertanyaan-pertanyaan yang harus dijawab oleh orang tua atau orang terdekat anak. Kuisioner yang dipilih adalah kuisioner dengan pertanyaan tertutup yaitu jawaban dari pertanyaan sudah tersedia, responden tinggal memilih jawaban sesuai dengan pertanyaan yang dimaksud.

Analisis data pada penelitian ini menggunakan analisis univariat berupa frekuensi dan persentase, serta analisis bivariat dengan menggunakan uji chi square untuk menganalisis hubungan antara variabel penggunaan gadget dengan perkembangan sosial dan emosianal anak. 
HASIL

\section{Karakteristik Responden}

Karakteristik responden pada penelitian ini sebagian besar memiliki orang tua yang berpendidikan pada tingkat SMA (46,9\%) dengan pekerjaan Ibu Rumah Tangga (44,4\%). Berdasarkan jenis kelamin jumlah responden laki-laki dan perempuan hampir seimbang dengan laki-laki 50,6\% dan perempuan $49,4 \%$.

\section{Analisis univariat}

Tabel 1: Distribusi Responden menurut Penggunaan Gadget

\begin{tabular}{lcc}
\hline \multicolumn{1}{c}{ Penggunaan Gadget } & $\mathrm{f}$ & $\%$ \\
\hline Rendah & 51 & 63 \\
\hline Tinggi & 30 & 37 \\
\hline Jumlah & 81 & 100 \\
\hline
\end{tabular}

Berdasarkan tabel di atas diketahui bahwa responden terbanyak adalah responden dengan penggunaan gadget rendah yaitu sebanyak 51 orang $(63 \%)$.

Tabel 2: Distribusi Responden menurut Perkembangan Sosial dan Emosional

\begin{tabular}{lcc}
\hline $\begin{array}{c}\text { Perkembangan Sosial } \\
\text { dan Emosional }\end{array}$ & f & $\%$ \\
\hline Baik & 41 & 50,6 \\
\hline Sedang & 24 & 29,6 \\
\hline Buruk & 16 & 19,8 \\
\hline Jumlah & 81 & 100 \\
\hline
\end{tabular}

Berdasarkan tabel di atas diketahui bahwa responden terbanyak adalah responden yang memiliki perkembangan sosial dan emosional baik yaitu sebanyak 41 orang $(50,6 \%)$.
Analisis bivariat

Tabel 3: Hubungan Penggunaan Gadget dengan Perkembangan Sosial dan Emosional Anak Prasekolah

\begin{tabular}{|c|c|c|c|c|c|c|c|c|}
\hline \multirow{3}{*}{$\begin{array}{l}\text { Pengguna- } \\
\text { an Gadget }\end{array}$} & \multicolumn{6}{|c|}{$\begin{array}{c}\text { Perkembangan Sosial dan } \\
\text { Emosional }\end{array}$} & \multicolumn{2}{|c|}{ Total } \\
\hline & \multicolumn{2}{|c|}{ Baik } & \multicolumn{2}{|c|}{ Sedang } & \multicolumn{2}{|c|}{ Buruk } & \multirow[t]{2}{*}{$f$} & \multirow{2}{*}{$\%$} \\
\hline & $f$ & $\%$ & $f$ & $\%$ & $f$ & $\%$ & & \\
\hline Rendah & 33 & 64,7 & 13 & 25,5 & 5 & 9,8 & 51 & 100 \\
\hline Tinggi & 8 & 26,7 & 11 & 36,7 & 11 & 36,7 & 30 & 100 \\
\hline Jumlah & 41 & 50,6 & 24 & 29,6 & 16 & 19,8 & 8 & 100 \\
\hline$p$ value & 0,00 & & & & & & & \\
\hline
\end{tabular}

Berdasarkan tabel di atas diketahui bahwa responden dengan penggunaan gadget rendah dan perkembangan sosial dan emosional baik adalah sebanyak $64,7 \%$ (33orang), sedangkan responden dengan penggunaan gadget tinggi dan perkembangan sosial dan emosional baik adalah sebanyak $26,7 \%$ (8 orang). Responden dengan penggunaan gadget rendah dan perkembangan sosial dan emosional sedang adalah sebanyak $25,5 \%$ (13 orang), sedangkan responden dengan penggunaan gadget tinggi dan perkembangan sosial dan emosional sedang adalah sebanyak $36,7 \%$ (11 orang). Responden dengan penggunaan gadget rendah dan perkembangan sosial dan emosional buruk adalah sebanyak 9,8\% (5 orang), sedangkan responden dengan penggunaan gadget tinggi dan perkembangan sosial dan emosional buruk adalah sebanyak $36,7 \%$ (11 orang).

Hasil uji statistik didapatkan p-value $=0,001<\alpha(0.05)$ artinya Ho ditolak sehingga dapat disimpulkan bahwa ada hubungan Penggunaan Gadget dengan Perkembangan Sosial dan Emosional Anak Prasekolah.

\section{PEMBAHASAN}

\section{Penggunaan Gadget}

Berdasarkan hasil penelitian dapat diketahui bahwa karakterisitik responden terbanyak adalah responden dengan penggunaan gadget rendah yaitu sebanyak $63 \%$ (51 orang). Hasil penelitian ini 
sejalan dengan hasil penelitian Trinika, 2015 tentang pengaruh penggunaan gadget terhadap perkembangan psikososial anak usia prasekolah (3-6 tahun) di TK Kristen Immanuel tahun ajaran 2014-2015, hasil penelitian didapatkan paparan penggunaan gadget yang rendah lebih banyak yaitu sebanyak 57,9\% (55 orang). Penelitian ini juga sesuai dengan teori yang disampaikan oleh Widiawati (2011) bahwa : gadget bukan barang asing untuk anak usia prasekolah (usia 3-6 tahun).

Penelitian lain yang dilakukan oleh Delima, Arianti dan Pramudyawardani (2015) diperoleh hampir semua orang tua (94\%) menyatakan bahwa anak mereka biasa menggunakan perangkat teknologi untuk bermain game. Teori lain yang mendukung hasil penelitian ini, yaitu : Karman (2013) menunjukan bahwa anakanak usia 6 tahun ke bawah sudah terlibat dalam penggunaan media dan teknologi baru semenjak lahir.

Berdasarkan teori dan hasil penelitian diatas, menurut peneliti penggunaan gadget pada anak prasekolah dalam penelitian ini dengan teori dan penelitian lain saling mendukung, sehingga peneliti mengambil kesimpulan bahwa anak prasekolah sudah menggunakan gadget dengan penggunaan gadget rendah dan penggunaan gadget tinggi. Hal ini terjadi karena perkembangan teknologi yang semakin pesat sehingga berpengaruh pada beberapa aspek kehidupan salah satunya pola dan cara pengasuhan anak yang dilakukan orang tua. Alasan lain dari penggunaan gadget pada anak prasekolah adalah takut anaknya ketinggalan perkembangan teknologi dan agar anak belajar selama masa tumbuh kembang. Padahal, pengaruh gadget dalam masa tumbuh kembang anak tidak terlalu signifikan karena hanya bersifat satu arah. Sedangkan tumbuh kembang anak yang optimal membutuhkan interaksi dua arah antara anak dan ibunya.

Peneliti mendapatkan data bahwa sebanyak $46,9 \%$ orang tua dari siswa di PAUD Percontohan Tunas Ceria memiliki tingkat pendidikan yang tinggi yaitu SMA, dan pekerjaan terbanyak adalah Ibu Rumah
Tangga yaitu 44,4\%, oleh sebab itu pengetahuan mereka cukup tinggi dan waktu mengawasi anak cukup luang untuk melakukan antisipasi dengan selalu mengontrol dan mengawasi anak-anaknya dalam penggunaan gadget sehingga penggunaan gadget anak prasekolah di PAUD Percontohan Tunas Ceria Tanjung Bintang dikategorikan rendah.

Menurut peneliti, sebaiknya setiap orang tua melakukan antisipasi dengan selalu mengontrol dan mengawasi anakanaknya dalam penggunaan gadget tersebut. Orang tua juga harus membatasi waktu penggunaan gadget dan lebih cerdas dalam memilah-milah aplikasi yang terdapat di gadget anak mereka. Orang tua juga harus selalu mendampingi anak ketika menggunakan gadget.

\section{Perkembangan Sosial dan Emosional}

Berdasarkan hasil penelitian yang telah dilakukan, dari 81 responden yang menjadi sampel penelitian didapatkan bahwa responden terbanyak adalah responden yang memiliki perkembangan sosial dan emosional baik yaitu sebanyak 41 orang $(50,6 \%)$. Hasil penelitian ini sejalan dengan hasil penelitian Trinika, 2015 tentang pengaruh penggunaan gadget terhadap perkembangan psikososial anak usia prasekolah (3-6 tahun) di TK Kristen Immanuel tahun ajaran 2014-2015, hasil penelitian didapatkan perkembangan sosial dan emosional yang baik lebih banyak yaitu sebanyak 58,9\% (56 orang)

$$
\text { Menurut Masitoh }
$$

Perkembangan sosial dan emosianal anak prasekolah adalah perolehan kemampuan berperilaku sesuai dengan tuntutan sosial pada suatu keadaan yang terangsang dari organisme mencakup perubahanperubahan yang disadari, yang mendalam sifatnya dari perubahan perilaku saat berusia 3-6 tahun. Kemampuan sosial dan emosional merupakan fondasi bagi perkembangan kemampuan anak berinteraksi dengan lingkungannya secara lebih luas. Dalam berinteraksi dengan orang lain, individu tidak hanya dituntut untuk mampu berinteraksi secara baik dengan orang lain, tetapi terkait juga 
didalamnya bagaimana ia mampu mengendalikan dirinya secara baik. Ketidakmampuan individu mengendalikan dirinya dapat menimbulkan berbagai masalah sosial dan emosional dengan orang lain. Anak yang mempunyai kemampuan sosial dan emosional yang baik akan dapat menyesuaikan diri dengan baik terhadap terhadap lingkungannya, keluarga, sekolah dan teman-temannya.

Perkembangan anak ditinjau dari aspek psikososial yang dikemukakan oleh Erikson, mengatakan bahwa anak dalam perkembangannya selalu dipengaruhi oleh lingkungan sosial untuk mencapai kematangan kepribadian pada anak (Hidayat, 2009).

Mengembangkan sosial emosional harus dilakukan sejak dini terutama pada usia taman kanak-kanak. Hal ini disebabkan karena pada masa tersebut anak mulai mengembangkan pergaulan dengan teman sebaya dilingkungan rumah dan di luar rumah. Bahkan anak-anak yang berbeda wilayah dengan mereka yang tentunya memiliki ciri khas budaya yang berbeda.

Hasil penelitian Rhoades, et al (2011) menunjukkan bahwa attention selama masa taman kanak-kanak mampu memediasi hubungan antara pengetahuan emosi, keterampilan atensi dan kompetensi akademik di kelas pertama dengan memperhitungkan dampak pendidikan ibu, pendapatan keluarga, usia anak, jenis kelamin. Temuan ini menjadi salah satu strategi untuk meningkatkan keberhasilan akademis masa depan anak-anak.

Peneliti mendapatkan data bahwa sebanyak $46,9 \%$ orang tua dari siswa di PAUD Percontohan Tunas Ceria memiliki tingkat pendidikan yang tinggi yaitu SMA, dan pekerjaan terbanyak adalah Ibu Rumah Tangga yaitu $44,4 \%$, oleh sebab itu pengetahuan mereka cukup tinggi dan memiliki cukup waktu luang untuk mengoptimalkan dan memaksimalkan tumbuh kembang anak terutama perkembangan sosial dan emosional anak. Orang tua banyak melakukan interaksi dua arah dengan anak sehingga perkembangan sosial dan emosional anak prasekolah di
PAUD Percontohan Tunas Ceria Tanjung Bintang dikategorikan baik. Sarana dan prasarana yang dimiliki PAUD Percontohan Tunas Ceria serta proses pembelajaran yang disesuaikan dengan tingkat perkembangan anak juga menjadi alasan perkembangan sosial dan emosional anak prasekolah baik.

Sebaiknya baik orang tua, pendidik, maupun lingkungan sekitar anak dapat selalu memperhatikan dan mendukung setiap fase perkembangan anak, terutama perkembangan psikososial anak usia prasekolah (3-6 tahun) karena masa prasekolah merupakan periode penting dalam proses tumbuh kembang manusia. Perkembangan dan pertumbuhan di masa itu menjadi penentu keberhasilan pertumbuhan dan perkembangan anak di periode selanjutnya.

\section{Hubungan Penggunaan Gadget terhadap Perkembangan Sosial dan Emosional Anak Prasekolah}

Berdasarkan analisis hubungan penggunaan gadget terhadap perkembangan sosial dan emosional anak prasekolah yang dilakukan pada 81 orang responden diketahui bahwa : Hasil penelitian ini sejalan dengan penelitian sebelumnya yang dilakukan oleh Yulia Trinika (2015) tentang Pengaruh Penggunaan gadget terhadap Perkembangan Psikososial Anak Usia Prasekolah di TK Swasta Kristen Immanuel, hasil penelitiannya menunjukkan bahwa terdapat perngaruh yang cukup signifikan antara penggunaan gadget dengan perkembangan psikosial $(P$ value $=0,005)$. Penelitian terkait yang mendukung penelitian ini adalah Kim (2013) yang menyatakan bahwa penggunaan media digital memiliki efek terhadap kemampuan perhatian anak seperti peningkatan hiperaktivitas dan kesulitan dalam berkonsentrasi serta mereka juga lebih banyak merasa sedih atau bosan dengan teman-temannya. Teori lain yang mendukung hasil penelitian ini, yaitu: Iswidharmanjaya dan Agency dalam buku Bila Si Kecil Bermain Gadget (2014) tentang dampak negatif penggunaan 
gadget pada anak, yaitu ketika anak telah kecanduan gadget, pasti akan menganggap perangkat itu adalah bagian dari hidupnya. Hal tersebut akan menganggu kedekatan anak dengan orang tuannya, lingkungannya, bahkan teman sebayanya.

Dengan adanya kesamaan antara hasil penelitian ini dengan teori dan penelitian terkait yang telah dilakukan sebelumnya, maka peneliti menyimpulkan bahwa memang benar ada hubungan penggunaan gadget dengan perkembangan sosial dan emosional anak prasekolah.

Peneliti mendapatkan data bahwa sebanyak $46,9 \%$ orang tua dari siswa di PAUD Percontohan Tunas Ceria memiliki tingkat pendidikan yang tinggi yaitu SMA, dan pekerjaan terbanyak adalah Ibu Rumah Tangga yaitu 44,4\%, oleh sebab itu pengetahuan mereka cukup tinggi dan waktu mengawasi anak cukup luang untuk melakukan antisipasi dengan selalu mengontrol dan mengawasi anak-anaknya dalam penggunaan gadget. Sehingga, dampak yang akan ditimbulkan dari gadget tersebut dapat dicegah. Orang tua juga lebih cerdas dalam memilah-milah aplikasi yang terdapat di gadget anak mereka dan selalu mendampingi anak ketika menggunakan gadget. Maka dari itu dampak negatif dari gadget terhadap perkembangan sosial dan emosional anak prasekolah di TK PAUD Percontohan Tunas Ceria ini tidak terlalu besar.

Menurut Jovita Maria Ferliana, M.Psi. (2013) ada beberapa cara yang bisa dilakukan oleh orang tua dalam mengatur anak menggunakan gadget ialah sebagai berikut:

\section{Pilih sesuai usia}

Untuk anak usia di bawah 6 tahun, Pemberian gadget sebaiknya hanya seputar pengenalan warna, bentuk, dan suara. Artinya, jangan terlalu banyak memberikan kesempatan bermain gadget pada anak di bawah 6 tahun. Terlebih di usia ini, yang utama bukan gadgetnya, tapi fungsi orang tua. Pasalnya gadget hanya sebagai salah satu sarana untuk mengedukasi anak.
Perkembangan otak anak akan lebih optimal jika anak diberi rangsangan sensorik secara langsung. Misalnya, meraba benda, mendengar suara, berinteraksi dengan orang, dan sebagainya. Pada saat bermain gadget, anak akan merasakan kesenangan, sehingga memicu meningkatnya hormon endorfin. kecanduan berhubungan dengan ini jika dilakukan dalam jangka waktu lama dan kontinyu . Akibatnya, ke depannya, anak akan mencari kesenangan dengan jalan bermain gadget, karena memang sudah terpola sejak awal perkembangannya.

Dari aspek interaksi sosial, perkembangan anak-anak usia di bawah 6 tahun sebaiknya memang lebih ke arah sensor-motorik. Yaitu, anak harus bebas bergerak, berlari, meraih sesuatu, merasakan kasar-halus. Memang di gadget juga ada pengenalan warna atau games di mana orang melompat. Namun, kemampuan anak untuk berinteraksi secara langsung dengan objek nyata di dunia luar tidak diperoleh anak.

\section{Batasi waktu}

Anak usia di bawah 6 tahun, bolehboleh saja diberi gadget. Tapi harus diperhatikan durasi pemakaiannya. Misalnya, boleh bermain tapi hanya setengah jam dan hanya pada saat senggang. Contohnya, kenalkan gadget seminggu sekali, misalnya hari Sabtu atau Minggu. Lewat dari itu, ia harus tetap berinteraksi dengan orang lain.

Sejalan pertambahan usia, ketika anak masuk usia pra remaja, orang tua bisa memberi kebebasan yang lebih, karena anak usia ini juga perlu gadget untuk fungsi jaringan sosial mereka. Di atas usia 5 tahun (mulai 6 tahun sampai usia 10 tahun) orang tua bisa memperbanyak waktu anak bergaul dengan gadget. Di usia ini, anak sudah harus menggali informasi dari lingkungan. Jadi, kalau tadinya cuma seminggu sekali selama setengah jam dengan supervisi dari orang tua, kini setiap Sabtu dan Minggu selama dua jam. Boleh main games atau browsing mencari informasi. Intinya, kalau orang tua sudah menerapkan kedisiplinan sedari awal, 
maka di usia pra remaja, anak akan bisa menggunakan gadget secara bertanggungjawab dan tidak kecanduan gadget.

\section{Hindarkan kecanduan}

Kasus kecanduan atau penyalahgunaan gadget biasanya terjadi karena orang tua tidak mengontrol penggunaannya saat anak masih kecil. Maka sampai remaja pun ia akan melakukan cara pembelajaran yang sama. Akan susah mengubah karena kebiasaan ini sudah terbentuk. Ini sebabnya, orang tua harus ketat menerapkan aturan ke anak, tanpa harus bersikap otoriter. Dan jangan lupa, orang tua harus menerapkan reward and punishment. Kalau ini berhasil dijalankan, maka anak akan bisa melakukannya secara bertanggungjawab dan terhindar dari kecanduan.

\section{Beradaptasi dengan zaman}

Salah satu dampak positif gadget adalah akan membantu perkembangan fungsi adaptif seorang anak. Artinya kemampuan seseorang untuk bisa menyesuaikan diri dengan keadaan lingkungan sekitar dan perkembangan zaman. Jika perkembangan zaman sekarang muncul gadget, maka anak pun harus tahu cara menggunakannya.

Artinya fungsi adaptif anak berkembang. seorang anak harus tahu fungsi gadget dan harus bisa menggunakannya karena salah satu fungsi adaptif manusia zaman sekarang adalah harus mampu mengikuti perkembangan teknologi. Sebaliknya, anak yang tidak bisa mengikuti perkembangan teknologi bisa dikatakan fungsi adaptifnya tidak berkembang secara normal.

Namun, fungsi adaptif juga harus menyesuaikan dengan budaya dan tempat seseorang tinggal. Kalau anak tinggal di sebuah desa dimana gadget adalah barang langka, maka wajar kalau anak tidak tahu dan tidak kenal yang namanya gadget.

Menurut Peneliti sebaiknya orang tua yang memiliki anak prasekolah agar memperhatikan penggunaan gadget pada anaknya, memilih aplikasi sesuai dengan usianya, serta membatasi waktu penggunaan gadget agar anak tidak mengalami kecanduan sehingga anak dapat beradaptasi dengan lingkungan dan terhindar dari keterlambatan perkembangan khususnya sosial dan emosional.

\section{KESIMPULAN}

Penelitian ini menyimpulkan bahwa ada hubungan penggunaan gadget dengan perkembangan sosial dan emosional anak prasekolah. Berdasarkan hasil kesimpulan yang di dapat dalam penelitian maka penulis menyarankan agar pendidik prasekolah untuk lebih memperhatikan proses tumbuh kembang anak khususnya perkembangan sosial dan emosional dengan cara pihak sekolah dapat mengirim pendidik untuk mengikuti kegiatan seminar terbaru yang berkaitan dengan penggunaan gadget anak prasekolah.

\section{DAFTAR PUSTAKA}

Anggrahini, S. A. (2013). Dinamika Komunikasi Keluarga Pengguna Gadget. Universitas Islam Negeri Sunan Kalijaga, Fakultas Ilmu Sosial dan Humaniora. Yogyakarta. (Skripsi)

Hidayat, A. A. (2009). Pengantar Ilmu Keperawatan Anak 1. Jakarta:

Salemba Medika.

Iswidharmanjaya, D., \& Agency, B. (2014). Bila Si Kecil Bermain Gadget. Jakarta : EGC.

Widiawati \& Sugiman. 2014. Pengaruh penggunaan gadget terhadap daya kembang anak. Diakses dari http://stmikglobal.ac.id/wpcontent/ uploads/2014/05/ARTIKELIIS.pdf pada tanggal 04 Januari 2017.

Winarno, Wing. 2009. Panduan Penggunaan Gadget. Jakarta: Rineka Cipta. 